\title{
Designing a Firing Control System on S-60 57mm Cannon
}

\author{
Kurnia Gunadi As'ad ${ }^{1 *)}$, Rachmad Setiawan ${ }^{2)}$, and Moch Rameli $^{3)}$ \\ ${ }^{1)}$ Sekolah Staf dan Komando Angkatan Laut \\ ${ }^{2,3)}$ Institut Teknologi Sepuluh Nopember, Surabaya \\ Corresponding Email: *) Gunadiasad@gmail.com
}

\begin{abstract}
The firing system on the $\mathrm{S}-6057 \mathrm{~mm}$ cannon uses the foot of the cannon crew, which is very dangerous with the position of the crew on top of the cannon when firing. So, a firing system that can be remotely controlled by a computer is required. The design of the $S-6057 \mathrm{~mm}$ gun firing control system uses a personal computer (PC) as the firing command input, with data communication using WiFi received by the Atmega8535 microcontroller as a voltage regulator for solenoids. The solenoid has a tensile force to drive the hydraulic system where the actuator functions to drive the firing cylinder. Accelero sensor MMA7361, as a variable controller in firing, provides input data simulating the tilt position of the cannon, the position of the $0 \mathrm{~g}$ sensor is simulated by the cannon in a balanced position. From the test results, there is a difference in sensor designation data with arc angles i.e., angle $X$ by 2.83 degrees and angle $Y$ by 1.86 degrees. The magnetic field produced by the solenoid $0.53 \mathrm{~T}$ can attract a maximum load of $20 \mathrm{~kg}$. By changing the distance ratio of mechanical lever to $39.11 \mathrm{~cm}$ and $8.89 \mathrm{~cm}$, the solenoid can drive an 88-kg firing cylinder.
\end{abstract}

Keywords: S-60 57mm cannon, Accelero MMA7361, AVR Atmega8535

\section{INTRODUCTION}

The development of increasingly advanced technology today, has encouraged the growing use of technology to support the military [1][2]. One of its application is the use of computers as weapons control [3][4]. The need for Fire Control System (FCS) in Indonesia has been fulfilled by overseas procurement or purchase. Thus, the level of dependence on other countries is very high and the purchase also costs a lot [5][4]. In repairing the system in case of damage, the service of foreign technicians is more likely to be used, where the time and cost depend on the company [6]. Therefore, the maintenance costs are also high.

One system that has been developed is the Gun Control System (GCS) on the S-60 57mm cannon made in Russia in 1950. This cannon began to strengthen the defense equipment of Indonesian National Armed Forces (TNI) since Trikora operation era in the early 60s. It is a singlebarreled Air Strike Repellent cannon with a low and medium target range [6].

The manual firing system of the S-60 57mm cannon uses crew control by stomping the firing pedal with the foot of the cannon crew, where the gun crew is on the gun platform. It is very risky for the cannon crew, e.g., accidents might occur when the ammunition fails to eject and explodes in the cannon barrel.

Therefore, to maximize the use of existing equipment while prioritizing zero accidents at the same time, it is necessary to design a remote cannon firing system so that the safety of crew or operators will not be compromised so that the use of this cannon can continue to be maximized to support the defense forces, especially in the Indonesian Navy (TNI AL).

This cannon has previously been developed by designing the Gun Control System (GCS) of the S-60 $57 \mathrm{~mm}$ cannon by STTAL students class of XXXII, but there are still many shortcomings, one of which is manual firing system, which has not been integrated with the created system [6].

\section{METHODOLOGY}

In general, the block diagram of the measurement system of angular position in the integrated navigation monitoring and gun control system design unit is shown in Figure 1.

Figure 1 represents the Figures system in general, this study discusses the part colored in red. Firing system is discussed in this paper and the tilt position of a cannon was simulated as input or variable in automatic firing.

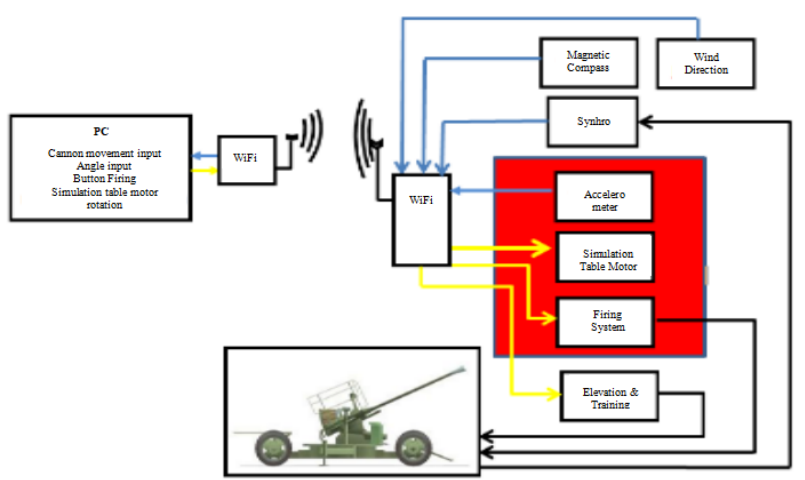

Figure 1. System block diagram

The PC functions to give firing orders manually or automatically. Manual firing commands will be received 
by the microcontroller to fire, while in automatic firing, the microcontroller considers the cannon tilt by simulating using the MMA7361 accelero sensor placed on the simulation table [4][7].

The simulation of the tilt effect can be controlled from a computer to drive the motor from the table leg, so that the table surface causes a tilt effect. Tilt data from the MMA7361 accelero sensor will then be sent to the computer.

\section{A. Hardware Design}

Hardware design includes the design of the firing system and cannon position simulation using the accelerometer sensor.

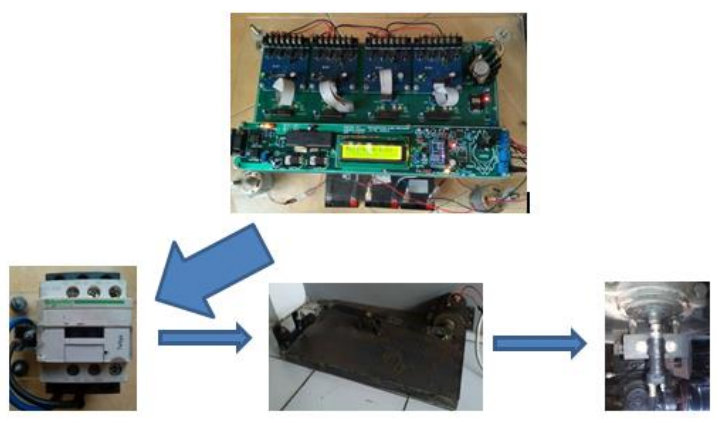

Figure 2. Design of firing system

In Figure 2, the electronic circuit which is the minimum system of the Atmega8535 AVR microcontroller serves to regulate the voltage required by the contactor of 24 VDC. The contactor acts as an electronic switch to supply the 220 VAC voltage required to drive the solenoid. Solenoids have a tensile force connected to the hydraulic system by using a lever. At the end of the hydraulic system, there is an actuator serving to press the firing cylinder.

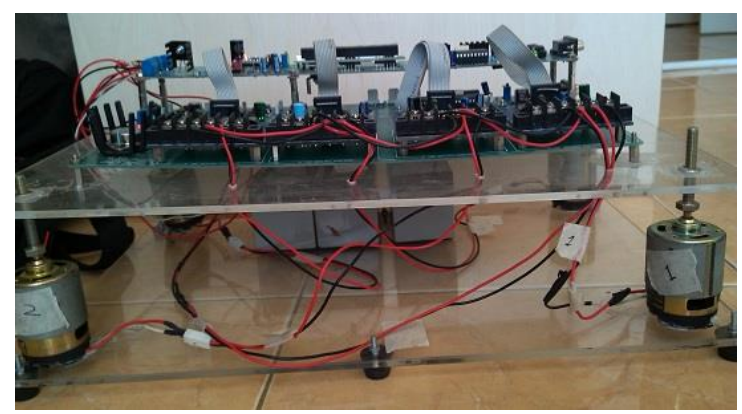

Figure 3. Simulation table of cannon position using accelero sensor

Figure 3 shows a table simulating the tilt position of the cannon where all four legs of the table use a DC motor that can be controlled in two-way: rotation up or down.

On the table, there is an accelero sensor MMA7361 which can read the slope that occurs due to changes in the position of the table surface with the rotation of four DC motors. The accelero sensor data is a simulation of the tilt of the cannon on the sailing ship as a simulation of changes due to sea waves, the data is represented in degrees of tilt pitch and roll [8].

\section{B. Software Design}

The software required to integrate into a complete system in the design of this weapon control system is built using the AVR language. The program's listing is incorporated into the AVR ATmega 8535 microcontroller to read accelero sensors and run solenoids for firing by operators from single computer control. Software creation includes [7]:

- AVR program into AVR ATmega 8535 microcontroller to run solenoids, read and display accelero sensor data as well as drive accelero sensor simulation motors.

- Weapons control display program using Borland Delphi7.

The full program listing will be displayed on the attachment sheet using the AVR language. The flowchart of the S60 57MM cannon firing control system can be seen in Figure 4

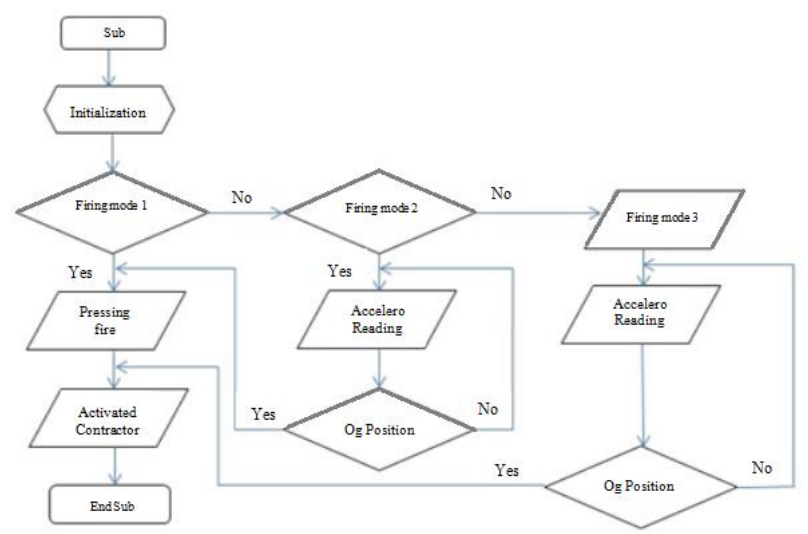

Figure 4. Flowchart of S-60 57mm cannon firing mode

Figure 4 describes the software algorithm. After initializing the port, if firing mode 1 (one) is selected, where the accelerometer sensor tilt data is ignored, pressing the fire button will cause 24 VDC to flow to the contactor voltage, resulting in the firing.

When firing mode 2 (two) is selected then the fire button is locked, the tilt data of the cannon from the accelerometer sensor will be taken. The fire button will function if the cannon tilt data fits the normal conditions. Otherwise, it will continue to loop, waiting for the cannon's normal position.

Firing mode 3 (three) is automatic fire mode. If the option is selected, the fire button will be locked, the cannon tilt data will be acquired from the accelerometer sensor. If it is appropriate, it will automatically fire without pressing the fire button.

\section{RESULTS AND DISCUSSION}

The conducted tests cover every part that makes up the system as a whole so it can be assessed whether the tools can function properly before being integrated as a whole. Tests carried out includes:

a. Accelero sensor testing 
b. Motor testing as a cannon tilt movement simulation table

c. Solenoid test

d. Mechanical testing of hydraulic system

\section{A. Accelero Sensor Test}

Accelero sensor testing was carried out on the output of the accelerometer sensor axis which has three axes, i.e., $\mathrm{X}$-axis, $\mathrm{Y}$-axis, and $\mathrm{Z}$-axis with two sensitivity options by setting the g-select position in the high $(+5 \mathrm{~V})$ or low $(0 \mathrm{~V})$ position. The g-select high has a sensitivity of $6 \mathrm{G}$, while the g-select low has a sensitivity of $1.5 \mathrm{G}$.

In this sensor test, the X-axis was tilted 900 to the left $(-1 \mathrm{~g})$ and 900 to the right $(+1 \mathrm{~g})$. Then for the $\mathrm{Y}$-axis was moved vertical 900 up $(+1 \mathrm{~g})$ and vertical 900 down $(-1 \mathrm{~g})$. Next, the z-axis was moved upside down 1800 . Table 1 summarizes the results of the angle measurement test according to the information described with different sensitivities.

Table 1. Test measurement limits Accelerometer g-select 0

\begin{tabular}{cccc} 
Axis & $\mathbf{- 1 g}$ & $\mathbf{0 g}$ & $\mathbf{+ 1 g}$ \\
\hline $\mathbf{X}$ & 248 & 499 & 750 \\
\hline $\mathbf{Y}$ & 289 & 540 & 790 \\
\hline $\mathbf{Z}$ & 0 & 666 & 171 \\
\hline
\end{tabular}

The results of the existing minimum limit $(-1 g)$, flat position (0), and maximum limit (1g) are used as a reference to calculate the inclination angle formed from the $\mathrm{X}$-axis to the $\mathrm{Z}$-axis and the $\mathrm{Y}$-axis to the $\mathrm{Z}$-axis.

The inclination angle of the $\mathrm{X}$-axis to the $\mathrm{Z}$-axis and the $\mathrm{Y}$-axis to the $\mathrm{Z}$-axis are obtained by entering the values of $+1 \mathrm{~g}, 0 \mathrm{~g}$, and $-1 \mathrm{~g}$.

The value of the $\mathrm{X}$-axis variables are :

$$
\begin{aligned}
\mathrm{X} 1 & =\frac{\{+1 \mathrm{~g}(\mathrm{x})\}+\{-1 \mathrm{~g}(\mathrm{x})\}}{2} \\
& =\frac{750+248}{2} \\
\mathrm{X} 1 & =499 \\
\mathrm{X} 2 & =\frac{\{+1 \mathrm{~g}(\mathrm{x})\}-\{-1 \mathrm{~g}(\mathrm{x})\}}{2} \\
& =\frac{750-248}{2} \\
\mathrm{X} 2 & =251
\end{aligned}
$$

The value of the $\mathrm{Y}$-axis variables are:

$$
\begin{aligned}
\mathrm{Y} 1 & =\frac{\{+1 \mathrm{~g}(\mathrm{y})\}+\{-1 \mathrm{~g}(\mathrm{y})\}}{2} \\
& =\frac{790+289}{2} \\
\mathrm{Y} 1 & =539.5
\end{aligned}
$$

$$
\begin{aligned}
\mathrm{Y} 2 & =\frac{\{+1 \mathrm{~g}(\mathrm{y})\}-\{-1 \mathrm{~g}(\mathrm{y})\}}{2} \\
& =\frac{790-289}{2} \\
\mathrm{Y} 2 & =250.5
\end{aligned}
$$

The value of the $\mathrm{Z}$-axis variables are:

$$
\begin{aligned}
\mathrm{Z} 1 & =\frac{\{+1 \mathrm{~g}(\mathrm{z})\}+\{0 \mathrm{~g}(\mathrm{z})\}}{2} \\
& =\frac{666+171}{2} \\
\mathrm{Z} 1 & =418.5 \\
\mathrm{Z} 2 & =\frac{\{+1 \mathrm{~g}(\mathrm{z})\}-\{0 \mathrm{~g}(\mathrm{z})\}}{2} \\
& =\frac{666-171}{2} \\
\mathrm{Z} 2 & =247.5
\end{aligned}
$$

The acceleration $\mathrm{x}, \mathrm{y}, \mathrm{z}$ are obtained with the following formula;

$$
\begin{aligned}
\mathrm{Ax}[\mathrm{i}] & =\frac{\text { current data of } \mathrm{X} \text {-axis- } \mathrm{X} 1}{\mathrm{X} 2} \\
& =\frac{\text { current data of } \mathrm{X} \text {-axis }-499}{251} \\
\mathrm{Ay}[\mathrm{i}] & =\frac{\text { current data of } \mathrm{Y} \text {-axis }-\mathrm{Y} 1}{\mathrm{Y} 2} \\
& =\frac{\text { current data of } \mathrm{Y} \text {-axis }-539.5}{250.5} \\
\mathrm{Az}[\mathrm{i}] & =\frac{\text { current data of } \mathrm{Z} \text {-axis }-\mathrm{Z} 1}{\mathrm{Z} 2} \\
& =\frac{\text { current data of } \mathrm{Z} \text {-axis- }-418.5}{247.5}
\end{aligned}
$$

The angles of the $\mathrm{X}$-axis and $\mathrm{Y}$-axis are:

$$
\begin{aligned}
& \theta x=\arctan \frac{A x[i]}{A z[i]} \\
& \theta y=\arctan \frac{A y[i]}{A z[i]}
\end{aligned}
$$

Based on the calculation, the angle on the $\mathrm{X}$-axis to the $\mathrm{Z}$-axis and the angle on the $\mathrm{Y}$-axis to the $\mathrm{Z}$-axis can be known.

After calculating the angle, the angle from the accelero sensor with the one generated by the arc were compared. Measurements were carried out 10 times every 10 degrees. An average of 10 measurements was obtained, as shown in Table 2 and Table 3. 
Table 2. Comparison of arc and sensor readings on $\mathrm{X}$-axis angle

\begin{tabular}{|c|c|c|c|c|c|}
\hline \multirow{2}{*}{$\begin{array}{c}\text { Arc } \\
\text { angle } \\
\text { reading } \\
\text { (X-axis) } \\
\text { (degrees) }\end{array}$} & \multicolumn{3}{|c|}{ Data Designation } & \multirow{2}{*}{$\begin{array}{c}\text { Sensor } \\
\text { angle } \\
\text { reading } \\
\text { (X-axis) } \\
\text { (degrees) }\end{array}$} & \multirow{2}{*}{$\begin{array}{c}\text { X-Axis } \\
\text { Difference } \\
\text { (degrees) }\end{array}$} \\
\hline & $\mathbf{X}$ & $\mathbf{Y}$ & $\mathbf{Z}$ & & \\
\hline $\mathbf{0}(\mathbf{0 g})$ & 497.2 & 542.8 & 673 & -0.57 & 0.57 \\
\hline $10(-1 g)$ & 465 & 539.2 & 670.8 & -7.58 & 2.42 \\
\hline $20(-1 g)$ & 424.5 & 542 & 661.2 & -16.87 & 3.13 \\
\hline $30(-1 g)$ & 386.4 & 549.1 & 646.1 & -26.05 & 3.95 \\
\hline $40(-1 g)$ & 351 & 551.8 & 623.3 & -35.56 & 4.44 \\
\hline $50(-1 g)$ & 312.4 & 550.7 & 588.9 & -47.28 & 2.72 \\
\hline $60(-1 g)$ & 291 & 543.7 & 557.9 & -55.9 & 4.1 \\
\hline $70(-1 g)$ & 272.4 & 540.4 & 523.4 & -64.97 & 5.03 \\
\hline $80(-1 g)$ & 258.7 & 541.6 & 484.1 & -74.66 & 5.34 \\
\hline $90(-1 g)$ & 253.7 & 541.7 & 433.3 & -86.65 & 3.35 \\
\hline $10(1 \mathrm{~g})$ & 544.8 & 537.6 & 669.3 & 10.22 & 0.22 \\
\hline $20(1 \mathrm{~g})$ & 592.1 & 544.3 & 656.9 & 21.09 & 1.09 \\
\hline $30(1 g)$ & 625.2 & 536.8 & 640.2 & 29.35 & 0.65 \\
\hline $40(1 \mathrm{~g})$ & 664.3 & 546.6 & 616.7 & 39.5 & 0.5 \\
\hline $50(1 \mathrm{~g})$ & 689.4 & 545.3 & 590.3 & 47.33 & 2.67 \\
\hline $60(1 \mathrm{~g})$ & 715.9 & 545.2 & 551.7 & 58.19 & 1.81 \\
\hline $70(1 \mathrm{~g})$ & 731.8 & 541.9 & 519.8 & 66.3 & 3.7 \\
\hline 80 (1g) & 743.8 & 543.9 & 477 & 76.51 & 3.49 \\
\hline $90(1 \mathrm{~g})$ & 749.7 & 544.1 & 439.7 & 85.25 & 4.75 \\
\hline
\end{tabular}

Table 3. Comparison of arc and sensor readings on $\mathrm{Y}$-axis angle

\begin{tabular}{|c|c|c|c|c|c|}
\hline \multirow{2}{*}{$\begin{array}{l}\text { Arc angle } \\
\text { reading } \\
\text { (X-axis) } \\
\text { (degrees) }\end{array}$} & \multicolumn{3}{|c|}{ Data Designation } & \multirow{2}{*}{$\begin{array}{c}\text { Sensor } \\
\text { angle } \\
\text { reading } \\
\text { (Y-axis) } \\
\text { (degrees) }\end{array}$} & \multirow{2}{*}{$\begin{array}{c}\text { Y-Axis } \\
\text { Difference } \\
\text { (degrees) }\end{array}$} \\
\hline & $\mathbf{X}$ & $\mathbf{Y}$ & $\mathbf{Z}$ & & \\
\hline $\mathbf{0}(\mathbf{0 g})$ & 502.4 & 592.7 & 669.6 & 1.18 & 1.18 \\
\hline $10(-1 g)$ & 500 & 479.6 & 663.9 & -13.58 & 3.58 \\
\hline $20(-1 g)$ & 502.6 & 439.1 & 649.1 & -23.31 & 3.31 \\
\hline $30(-1 g)$ & 503.2 & 400.9 & 628.9 & -33.11 & 3.11 \\
\hline $40(-1 g)$ & 504.2 & 369 & 602.2 & -42.6 & 2.6 \\
\hline $50(-1 g)$ & 502.8 & 343.3 & 570.1 & -52.07 & 2.07 \\
\hline $60(-1 g)$ & 501.6 & 323.2 & 540.5 & -60.4 & 0.4 \\
\hline $70(-1 g)$ & 499.7 & 308.4 & 505 & -69.37 & 0.93 \\
\hline 80 (-1g) & 502.7 & 296.8 & 463.8 & -79.44 & 0.56 \\
\hline $90(-1 g)$ & 503.8 & 292.8 & 420.7 & -89.72 & 0.28 \\
\hline $10(1 \mathrm{~g})$ & 502.4 & 592.7 & 669.6 & 11.84 & 1.84 \\
\hline $20(1 \mathrm{~g})$ & 500.3 & 638.7 & 658.4 & 22.26 & 2.26 \\
\hline $30(1 \mathrm{~g})$ & 502.7 & 675.6 & 639.6 & 31.36 & 1.36 \\
\hline $40(1 \mathrm{~g})$ & 500.3 & 706.9 & 614.4 & 40.24 & 0.42 \\
\hline $50(1 \mathrm{~g})$ & 499.9 & 741.1 & 582 & 50.71 & 0.71 \\
\hline
\end{tabular}

\begin{tabular}{|c|c|c|c|c|c|}
\hline \multirow{2}{*}{$\begin{array}{c}\text { Arc angle } \\
\text { reading } \\
\text { (X-axis) } \\
\text { (degrees) }\end{array}$} & \multicolumn{3}{|c|}{ Data Designation } & \multirow{2}{*}{$\begin{array}{c}\text { Sensor } \\
\text { angle } \\
\text { reading } \\
\text { (Y-axis) } \\
\text { (degrees) }\end{array}$} & \multirow{2}{*}{$\begin{array}{c}\text { Y-Axis } \\
\text { Difference } \\
\text { (degrees) }\end{array}$} \\
\hline & $\mathbf{X}$ & $\mathbf{Y}$ & $\mathbf{Z}$ & & \\
\hline $60(1 \mathrm{~g})$ & 499.6 & 761.2 & 548.2 & 59.47 & 0.53 \\
\hline $70(1 \mathrm{~g})$ & 499.4 & 776.7 & 513 & 68.16 & 1.84 \\
\hline $80(1 \mathrm{~g})$ & 499.6 & 783.6 & 480.2 & 75.78 & 4.22 \\
\hline $90(1 \mathrm{~g})$ & 499.6 & 785.5 & 437.4 & 85.71 & 4.29 \\
\hline \multicolumn{5}{|c|}{ Average error difference ( $\mathrm{Y}$-axis angle) } & 1.86 \\
\hline
\end{tabular}

From Table 2 and Table 3, the measurements using an arc with the sensor designation indicates an average difference of the $\mathrm{X}$-axis and $\mathrm{Y}$-axis by 2.83 and 1.86 degrees, respectively.

\section{B. Motor testing as the simulation of cannon tilt movement}

The tilt effect of the cannon position was simulated using a table with $4 \mathrm{DC}$ motors as its legs that can rotate in two directions, so the table surface can change according to the rotation of the motor. On the table, there was an accelero sensor so that the tilt position of the table simulated the tilt position of the cannon.

The four table legs made of DC motors must be able to move in both directions so that the table surface is not flat and able to tilt. To test the rotation of the four DC motors, measurements were made of the input and output of the H-bridge EMS 5A DC motor driver as the input from the DC motor [9], as shown in Figure 5.

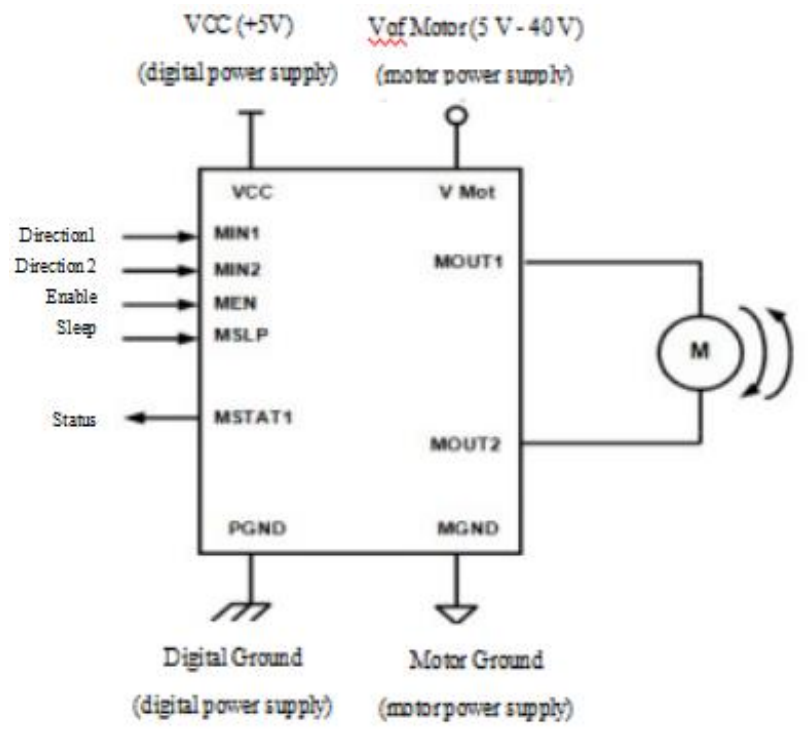

Figure 5. Motor rotation testing

Measurements were made to determine the input and output of the DC motor driver which serves to provide input to the motor so it can rotate to the right or left.

In Table 4, the output voltage of the $\mathrm{H}$-bridge driver can produce a voltage of \pm 12 VDC for motor rotation to the right and \pm 12 VDC for motor rotation to the left. 
Table 4. DC motor driver input and output test results

\begin{tabular}{llccccc}
\hline $\begin{array}{l}\text { H-Bridge } \\
\text { module } \\
\text { working } \\
\text { status }\end{array}$ & \multicolumn{4}{c}{ Input } & \multicolumn{4}{c}{$\begin{array}{c}\text { Status } \\
\text { Flag }\end{array}$} & $\begin{array}{c}\text { Output } \\
(\text { V) }\end{array}$ \\
\cline { 2 - 7 } & LP & MEN & $\begin{array}{c}\text { MIN } \\
\text { 1 }\end{array}$ & $\begin{array}{c}\text { MIN } \\
\text { 2 }\end{array}$ & $\begin{array}{c}\text { MST } \\
\text { AT1 }\end{array}$ & MOUT \\
\hline $\begin{array}{l}\text { Turn left } \\
\text { Motor 1 }\end{array}$ & H & H & H & L & H & 11.5 \\
\hline $\begin{array}{l}\text { Turn right } \\
\text { Motor 1 }\end{array}$ & H & H & L & H & H & -11.4 \\
\hline $\begin{array}{l}\text { Turn left } \\
\text { Motor 2 }\end{array}$ & H & H & H & L & H & 11.5 \\
\hline $\begin{array}{l}\text { Turn right } \\
\text { Motor 2 }\end{array}$ & H & H & L & H & H & -11.2 \\
\hline $\begin{array}{l}\text { Turn left } \\
\text { Motor 3 }\end{array}$ & H & H & H & L & H & 11.6 \\
\hline $\begin{array}{l}\text { Turn right } \\
\text { Motor 3 }\end{array}$ & H & H & L & H & H & -11.6 \\
\hline $\begin{array}{l}\text { Turn left } \\
\text { Motor 4 }\end{array}$ & H & H & H & L & H & 11.2 \\
\hline $\begin{array}{l}\text { Turn right } \\
\text { Motor 4 }\end{array}$ & H & H & L & H & H & -11.5 \\
\hline
\end{tabular}

\section{Solenoid testing}

The solenoid, which is a source of energy or tensile force used to drive the mechanics of the hydraulic system, pushes the deviation of the firing cylinder so that the firing process occurs.

The solenoid is $13 \mathrm{~cm}$ long, with an iron core diameter of $3 \mathrm{~cm}$, supplied voltage 220 VDC $10.9 \mathrm{~A}$, and wire coil with a diameter of $0.7 \mathrm{~mm}$. The number of twists per saft are 180 coils and 28 safts were used, so the total number of coils are 180 coils $\times 28$ safts $=5,040$ coils

The magnitude of the magnetic field on the solenoid is:

$$
\text { Bo }=\frac{\mu o \mathrm{I} \mathrm{N}}{\mathrm{L}}
$$

$B o=$ magnetic field at the center of the solenoid $(T)$

$\mu 0=$ vacuum permeability

$I=$ electric current $(A)$

$N=$ number of twists in solenoid

$L=$ length of solenoid $(\mathrm{m})$

Bo $=\frac{4 \pi \times 10^{-7} \times 10.9 \times 5,040}{0.13}$

Bo $=5,307,662.77 \times 10^{-7} \mathrm{~T}$

$\mathrm{Bo}=0.53 \mathrm{~T}$

The magnetic field force on the solenoid is very important in the calculation of the force pulling the load to be moved. To test the strength of solenoids, data was taken to determine the strength of the solenoid.

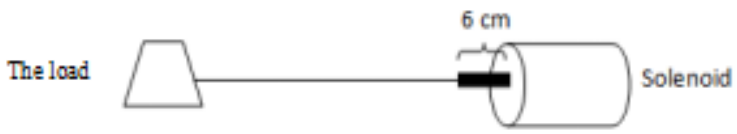

Figure 6. Solenoid pulling the load

Tests were carried out using loads from $5 \mathrm{~kg}$ to $30 \mathrm{~kg}$.
The load was pulled using a $150 \mathrm{~cm}$ long rope that connected the load to the solenoid as in Figure 6, the load was placed on the floor (ceramic) so the frictional force is neglected.

Table 5. Test result of solenoid strength distance test in pulling the load

\begin{tabular}{ccc} 
Test & Load & Solenoid power distance \\
\hline $\mathbf{1}$ & $5 \mathrm{~kg}$ & $28 \mathrm{~cm}$ \\
\hline $\mathbf{2}$ & $10 \mathrm{~kg}$ & $24 \mathrm{~cm}$ \\
\hline $\mathbf{3}$ & $15 \mathrm{~kg}$ & $9 \mathrm{~cm}$ \\
\hline $\mathbf{4}$ & $20 \mathrm{~kg}$ & $6 \mathrm{~cm}$ \\
\hline $\mathbf{5}$ & $25 \mathrm{~kg}$ & $4 \mathrm{~cm}$ \\
\hline $\mathbf{6}$ & $30 \mathrm{~kg}$ & $1 \mathrm{~cm}$ \\
\hline
\end{tabular}

Table 5 implies that the maximum load that can be pulled by the solenoid with a full pull of $6 \mathrm{~cm}$ according to the length of the solenoid cylinder is $20 \mathrm{~kg}$. So, the loads that can be fully pulled by the solenoid are the ones less than $20 \mathrm{~kg}$.

\section{Mechanical testing of hydraulic system}

It was conducted by testing the mechanics of the hydraulic system to find out if it can move the firing cylinder with the power from the solenoid. In this case, the author tested the hydraulic system and drove mechanics that connect the hydraulic pump to the solenoid.

The hydraulic system uses the upper clutch master as a hydraulic pump and the lower one as an actuator to drive the firing cylinder actuator, some of which were connected using a flexible hose that was fed with dot 3 fluid which is usually used as clutch oil or brake fluid in cars.

The hydraulic pump was connected using a flexible hose to the actuator and fluid was flowed in a 1-meter-long flexible hose and ensured that there were no leaks so the system could work to move the actuator. The basic principle of the hydraulic system is explained in Figure 7.

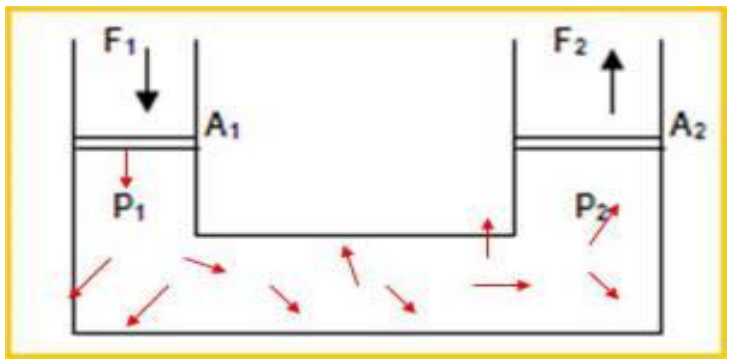

Figure 7. Fluid pressure in hydraulics

When the A1 cross-section is pressed by $\mathrm{F} 1$ force, then the $\mathrm{A} 2$ cross-section will be pushed up. So the law applies; $\mathrm{P} 1=\mathrm{P} 2$

$\mathrm{F} 1: \mathrm{F} 2=\mathrm{A} 1: \mathrm{A} 2$

Because the cross-sectional area of the hydraulic pump and that of the actuator are the same, the magnitude of the 
hydraulic actuator's thrust is equal to the maximum tensile force of the solenoid, which is capable of pushing a $20-\mathrm{kg}$ load.

To drive a hydraulic pump with a solenoid, a mechanical system was needed, in this case using a lever system as shown in Figure 8. The solenoid has a tensile force while a hydraulic pump requires a thrust. The length of the lever used is $48 \mathrm{~cm}$ with the pedestal in the middle of the lever is $24 \mathrm{~cm}$ long. So, the effort arm (Lk) is the same as the load arm (Lb).

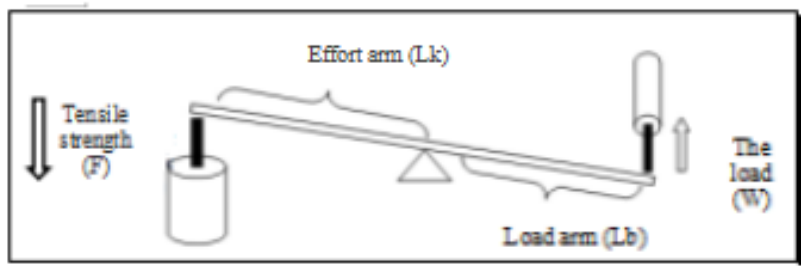

Figure 8. Hydraulic system mechanics

The amount of force or power source needed to move the load can be calculated using the lever system formula.

$$
\mathrm{F} \times \mathrm{Lk}=\mathrm{W} \times \mathrm{Lb}
$$

When the test was carried out with the pedestal position in the middle or the ratio between the effort arm and the load arm is the same, with the cylindrical core coming out of the solenoid for $3 \mathrm{~cm}$, the data obtained is shown in Table 6.

Table 6. Solenoid test against firing cylinder load

\begin{tabular}{cc}
\hline Test & Iron core shifting distance $(\mathbf{c m})$ \\
\hline $\mathbf{1}$ & 0.7 \\
\hline $\mathbf{2}$ & 0.6 \\
\hline $\mathbf{3}$ & 0.7 \\
\hline $\mathbf{4}$ & 0.8 \\
\hline $\mathbf{5}$ & 0.6 \\
\hline
\end{tabular}

Table 6 indicates that the solenoid could pull the load but not in full distance. The iron core cylinder coming out of the $3 \mathrm{~cm}$ long solenoid was only able to pull an average of $0.68 \mathrm{~cm}$. Thus, the ratio of the cannon firing cylinder load to the solenoid pull force is $0.68: 3$ or $1: 4.41$, so it can be assumed that the $20 \mathrm{~kg} \times 4.41$ cannon firing cylinder load is equal to $88 \mathrm{~kg}$.

Moving an 88-kg load with a maximum tensile strength of $20 \mathrm{~kg}$ can be done by changing the length ratio of the load arm (lb) and the effort arm (lk) with an overall length of $48 \mathrm{~cm}$.

It can be solved by the equation;

$$
\begin{aligned}
& \mathrm{F} \times \mathrm{Lk}=\mathrm{W} \times \mathrm{Lb} \\
& 20 \mathrm{Lk}=88 \mathrm{Lb} \\
& L k=\frac{88}{20} L b \\
& \mathrm{Lk}=4.4 \mathrm{Lb} . . . . .
\end{aligned}
$$

$$
\begin{aligned}
L k+L b & =48 \\
L b & =48-L k .
\end{aligned}
$$

From equation (i) and equation (ii) can be obtained;

$$
\begin{aligned}
& \mathrm{Lk}=4.4 \mathrm{Lb} \\
& \mathrm{Lk}=4.4(48-\mathrm{Lk}) \\
& \mathrm{Lk}=211.2-4.4 \mathrm{Lk} \\
& \mathrm{Lk}+4.4 \mathrm{Lk}=211.2 \\
& 5.4 \mathrm{Lk}=211.2 \\
& \quad \mathrm{Lk}=\frac{211.2}{5.4} \\
& =39.11 \mathrm{~cm} \\
& \mathrm{Lb}=48-\mathrm{Lk} \\
& =48-39.11 \\
& =8.89 \mathrm{~cm}
\end{aligned}
$$

From the above equation, to move an $88-\mathrm{kg}$ firing cylinder with a solenoid pull force of $20 \mathrm{~kg}$, the length ratio of the lever between the load arm and the effort arm is $8.89 \mathrm{~cm}$ and $39.11 \mathrm{~cm}$, respectively.

\section{CONCLUSION}

The firing mechanism of the S-60 57mm cannon employs the cannon crew's foot, which is extremely hazardous due to the crew's location on top of the cannon during firing. As a result, a firing mechanism that can be controlled remotely by a computer is necessary. The firing command input for the S-60 $57 \mathrm{~mm}$ gun firing control system is a personal computer (PC), with data transfer through $\mathrm{WiFi}$ received by the Atmega8535 microcontroller, which also serves as a voltage regulator for solenoids. The solenoid has a tensile force that drives the hydraulic system, which in turn drives the firing cylinder via the actuator. As a variable controller in firing, the accelero sensor MMA7361 gives input data mimicking the tilt position of the cannon, with the $0 \mathrm{~g}$ sensor's position replicated by the cannon in a balanced position. According to the test results, there is a discrepancy in sensor identification data with arc angles of 2.83 degrees and 1.86 degrees, respectively. A maximum load of $20 \mathrm{~kg}$ may be drawn by the magnetic field created by the solenoid $0.53 \mathrm{~T}$. The solenoid can operate an $88-\mathrm{kg}$ firing cylinder by adjusting the distance ratio of the mechanical lever to $39.11 \mathrm{~cm}$ and $8.89 \mathrm{~cm}$.

\section{REFERENCES}

[1] J.-F. He, J. Jin, B.-P. Li, Z.-M. Ye, and J.-W. Han, "Development of 6-DOF motion simulator for firing control system testing," Harbin Gongye Daxue Xuebao(Journal Harbin Inst. Technol., vol. 42, no. 7, pp. 1066-1070, 2010.

[2] Y. Wuyun and X. Deyou, "Detection Instrument for Firing Control System of Certain Type Self Parallel Gun [J]," Ordnance Ind. Autom., vol. 12, 2010.

[3] J. Axelson, "Networks for Monitoring and Control Using an RS-485 interface," Microcomput. J., vol. 1, p. 27, 1995. 
[4] R. Setiawan, Bahan Kuliah Mikrokontroller MCS-51. Surabaya, 2006.

[5] P. Rudakevych and M. Ciholas, "PackBot EOD firing system," in Unmanned Ground Vehicle Technology VII, 2005, vol. 5804, pp. 758-771.

[6] Sugiarto, "Perancangan Sistem Penggerak Baringan Dan Elevasi Dengan Basis Kontroler PD - PI Kaskade Pada Meriam S60 57mm,” STTAL Surabaya, 2013.

[7] A. Corporation, "8-bit Microcontroller with 16K Bytes In System Programmable Flash - Atemega 8535.” pp. 1-22, 2006.

[8] Elektro-Kontrol, "PENGUKURAN KEMIRINGAN MENGGUNAKAN ACCELEROMETER MMA7260 DENGAN CODEVISION AVR TERKALIBRASI," 2011. [Online]. Available: http://elektrokontrol.blogspot.com/2011/06/pengukuran-kemiringanmenggunakan.html. [Accessed: 24-Jun-2021].

[9] I. Electronics, "5 A H-Bridge," 2007. http://www.innovative electronics.com / index.php? pg= ie_pdet\&idp=174. 